\title{
Atopic dermatitis in children: Epidemiological and clinical aspects in Côte d'Ivoire
}

\section{Kouadio Celestin Ahogo', Yao Isidore Kouassi', Ildevert Patrice Gbery', Kouadio Richard Azagoh'2, Kouame Issouf Yeboua', Kouame Alexandre Kouassi', Ange Sylvain Allou ${ }^{1}$}

\begin{abstract}
${ }^{1}$ Dermatology Service, Félix Houphouët Boigny University, CHU Treichville, Abidjan, Côte d'Ivoire , ${ }^{2}$ Pediatric service, Félix Houphouët Boigny University, CHU Treichville, Abidjan, Côte d'Ivoire
\end{abstract}

Corresponding author: Dr. Kouadio Celestin Ahogo, E-mail: ahogoceleste@yahoo.fr

\begin{abstract}
Few studies have been devoted to atopic dermatitis in children in sub-Saharan Africa. We therefore make this study in Côte d'Ivoire in order to contribute to a better knowledge of atopic dermatitis in children on black skin. In our study the prevalence was $9.2 \%$. The duration of the disease before the consultation ranged from 3-45 days. Atopic dermatitis occurs more frequently in children from 2 to 5 years old. More than half of the patients had a history of atopy and the lesions generally were localized in the folds. $60 \%$ of the lesions were dry and were trigged by dust. The pruritus was often insomnia and the scratching leads to hyperpigmentation of the lower eyelid; a characteristic sign on black skin not often reported in the literature.
\end{abstract}

Key words: Atopic dermatitis; Children; Black skin; Cote d'Ivoire

\section{INTRODUCTION}

Atopic dermatitis or constitutional eczema usually occurs in children in a particular condition called atopy. Its pathophysiological, epidemiological, clinical and therapeutic aspects have been the subject of several studies in Europe and in America [1,2]. However, few studies have beendevoted to atopic dermatitis in sub-Saharan Africa. Therefore, we proposed to make this study in order to contribute to a better knowledge of atopic dermatitis in children, on black skin in Africa.

\section{MATERIALS AND METHODS}

This was a prospective study, with descriptive and analytical sight over 12 months. The target population waspatients seen in consultation over the period of our study. Boys and girls from 0 to 15 years with atopic dermatitis were included in the study. Data from the study were collected on an inquiry sheet that included socio-demographic and clinical data.

\section{Ethics Statement}

This article has been written by these authors, it has not been send or published by another journal.

\section{RESULTS}

On epidemiologic stage, 70 cases of atopic dermatitis have been recorded out of a total of 765 children seen in consultation. The prevalence of atopic dermatitis in children was $9.2 \% .52 .9 \%$ of the patients were male with a sex ratio $(\mathrm{M} / \mathrm{F})$ at 1.1. The age of the children's ranged from 6 months to 13 years. Children from 2 to 5 years represented $42.9 \%$ of the patients, followed by the age group from 6 to 13 years $(30 \%)$. The duration of the disease before the consultation ranged from 3-45 days. Outbreaks of the disease were more than 15 days in $72.4 \%$ of cases.

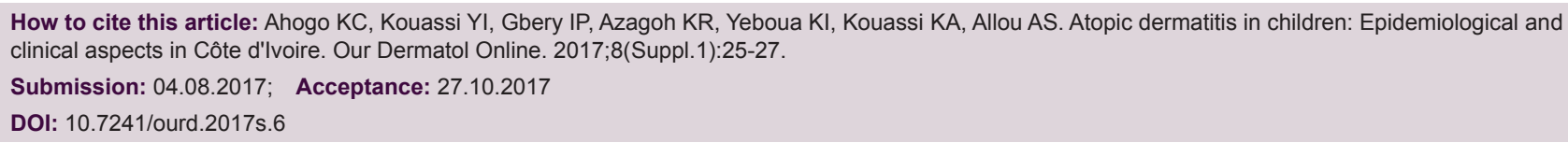


A triggering factor was found in $15.7 \%$ of our patients, it was mainly dust (17.1\%) and perfumes $(5.7 \%)$. The personal and family histories of atopy are represented in Table I.

The types of eczema observed were: dry (60\%), oozing $(32.9 \%)$, and lichenification $(07.1 \%)$. These lesions were found in the folds (54.3\%), the trunk (51.4\%), the legs $(31.4 \%)$, and the face (30\%) with pigmentation of the lower eyelid (7.1\%). The scalp (22.9\%) and generalized $(02.9 \%)$. Atopic dermatitis was minor in $57.1 \%$ of cases, moderate $(40 \%)$, and severe $(2.9 \%)$; the other signs of atopic dermatitis observed in children are represented in Table II. Complications were observed in $58.57 \%$ of children. These included insomnia pruritus (44.3\%), bacterial $(12.9 \%)$ and viral $(1.4 \%)$ secondary infection.

\section{DISCUSSION}

70 cases of atopic dermatitis was observed among 765 pediatric dermatoses, the prevalence was therefore 9.2\%. In Western Europe, the prevalence of atopic dermatitis in children is between $10-20 \%[3,4]$. The most affected age group in the study was 2 to 6 years. In fact, atopic dermatitis often begins duringthe first year of life (the new born) and decreases around the age

Table 1: Personal and family histories of atopy

\begin{tabular}{lcccc} 
& $\begin{array}{c}\text { Personal history } \\
\text { of atopie }\end{array}$ & $\begin{array}{c}\text { Family history of } \\
\text { atopy }\end{array}$ \\
\cline { 2 - 5 } & $(\mathbf{n})$ & $\begin{array}{c}\text { Percentage } \\
(\mathbf{n} \times 100 / 70)\end{array}$ & $\mathbf{( n )}$ & $\begin{array}{c}\text { Percentage } \\
(\mathbf{n} \times 100 / 70)\end{array}$ \\
Allergic rhinitis & 26 & 37.1 & 7 & 10 \\
Asthma & 18 & 25.7 & 31 & 44.3 \\
Allergic conjunctivitis & 12 & 17.1 & 3 & 4.4 \\
Atopic dermatitis & & & 23 & 32.8 \\
Food allergy & 6 & 8.6 & & \\
No atopic disease & 30 & 42.86 & 23 & 32.8 \\
\hline
\end{tabular}

Table 2: Other signs of atopic dermatitis

\begin{tabular}{lcc} 
Autres signes & $\begin{array}{c}\text { Effective } \\
\text { (n) }\end{array}$ & $\begin{array}{c}\text { Perrcentage } \\
(\mathbf{n} \times 100 / 70)\end{array}$ \\
Xérosis & 54 & 77.1 \\
Kératosis pilaris & 27 & 38.8 \\
Eczématides & 24 & 34.3 \\
Prurigo & 15 & 21.4 \\
Hyperlinerpalmar & 12 & 17.1 \\
Retro-auriculare fissure & 9 & 12.9 \\
Chéilitis & 9 & 12.9 \\
Hyperpigmentation of lower eyelid & 5 & 7.1 \\
Lichénification & 4 & 5.7 \\
Nail involvement & 4 & 5.7 \\
Denni Morgan sign & 2 & 1.4 \\
No other sign & 6 & $8.6 \%$ \\
\hline
\end{tabular}

of 5 years. $54.2 \%$ of the children had a history of atopic disease. These included allergic rhinitis (37.1\%), asthma (25.7\%) and allergic conjunctivitis (17.1\%). Six (06) of our patients regularly developed a food allergy. The association of several atopic clinical signs in the same patient is classic but inconstant $[5,6]$. The duration of relapses was in $72.4 \%$ of cases longer than 15 days. This could be explained in our context by self-medication. In one-quarter of the patients dust (17.1\%)was the triggerfactor. Atopic dermatitis is a multifactorial disease modulated by genetic and environmental influences $[7,8]$. Concerning the clinical aspects, atopic dermatitis in our study was predominantly in folds (54.3\%). This predominance in folds was mostly observed in children over 2 years of age. As for the nursling, they had mainly facial lesions. Dry lesions $(60 \%)$ were the most frequent, followed by oozing lesions (32.9\%). Seepage often represents an entry point for bacterial and viral complications of atopic dermatitis $[9,10]$. In fact, bacterial secondary infection occurred in $12.9 \%$ of cases. Lichenification was present in $7.1 \%$ of our patients. Chronic scratching is the main factor of thisLichenification. Insomnia pruritus was found in $44.3 \%$ of our patients. Pruritus leads to sleep disturbances, sometimes with children's growth retardation [11]. Instead, hyperpigmentation was observed on thelower eyelid (7.1\%). This characteristic sign most visible on dark skin is due to chronic friction.

\section{CONCLUSION}

Atopic dermatitis in Côte d'Ivoire occurs more frequently in children from 2 to 5 yearsold. More than half of the patients had a history of atopy and the lesions generally localized in the folds. These were mainly dry lesions most often triggered by dust. The pruritus was often insomnia and the scratching lead to hyperpigmentation of the lower eyelid; a characteristic sign on black skin not often reported in the literature.

\section{REFERENCES}

1. Catteau B. Atopic dermatitis: current epidemiology and clinical data. French J Allergol Clin Immunol. 2002;42:373-7.

2. Schmitt J, Langan S, Deckert S, Svensson A, von Kobyletzki L, Thomas K, et al. Assessment of clinical Signs of atopic dermatitis: A systematic review and recommendation. J Allergy Clin Immunol. 2013;132:1337-47.

3. Taïeb A. Atopic dermatitis: definition, epidemiology, natural history, gravity and scores. Ann Dermatol Venereol. 2005132:35-43.

4. Akdis CA, Akdis M, Bieber T, Bindslev-Jensen C, Boguniewicz M, Eigenmann P, et al. Diagnosis and treatment of atopic dermatitis in children and adults: European Academy of Allergology and Clinical Immunology/American Academy of Allergy, Asthma 


\section{www.odermatol.com}

and Immunology/PRACTALL Consensus Report. J Allergy Clin Immunol. 2006;118:152-69.

5. Asher MI, Montefort S, Björkstén B, Lai CK, Strachan DP, Weiland SK, et al. Worldwide time trends In the prevalence of symptoms of asthma, allergic rhinitis conjunctivitis, and eczema in childhood: ISAAC Phases One and Three repeat multi-crosssectional surveys. Lancet. 2006;368:733-43.

6. The prevalence of asthma, rhinitis and eczema in 13 to 14 years old children in Africa: The ISAAC Phase III. Allergy. 2007;3:247-58.

7. Borralevi T, Hubiche T, Léauté-Labrèze C, Saubusse E, Fayon M, Roul S, et al. Epicutaneous aeroallergen sensitization in atopic dermatitis infants determine the role of epidermal barrier impairment. Allergy. 2008;63:205-10.

8. Dominguez-Bello MG, Costello EK, Contreras M, Magris M, Hidalgo G, Fierer N, et al. Delivery mode shapes the acquisition and structure of the initial microbiota across multiple body habitats in newborns. Proc Natl Acad Sci U S A. 2010;107:11971-5.

9. Sidbury R, Davis DM, Cohen DE, Cordoro KM, Berger TG,
Bergman JN, et al. Guidelines for the management of atopic dermatitis: section 2. Management and treatment of atopic dermatitis with topical therapies. J Am Acad Dermatol. 2014;71:116-32.

10. Kong HH, Oh J, Deming C, Conlan S, Grice EA, Beatson MA, et al. Temporal shifts in the skin Atopic dermatitis. Genome Res. 2012;22:850-9.

11. Silverberg JI, Simpson EL. Association between severe eczema in children and multiple comorbid conditions and increased health care utilization. Pediatr Allergy Immunol. 2013;24:476-86.

Copyright by Kouadio Celestin Ahogo, et al. This is an open-access article distributed under the terms of the Creative Commons Attribution License, which permits unrestricted use, distribution, and reproduction in any medium, provided the original author and source are credited.

Source of Support: Nil, Conflict of Interest: None declared. 